\title{
A Quantitative Evaluation of the Relative Efficiency of Gelatine and Albumin in Preventing Insulin Adsorption to Glass
}

\author{
By \\ P. H. Sönksen, J. P. Ellis, C. Lowy, A. Rutherford and J. D. N. Nabarro \\ From The Institute of Clinical Research and The Institute of Nuclear Medicine; The Middlesex Hospital Medical \\ School, London W. 1.
}

Received June 17, 1965

Summary. Albumin has been found to be more effective than gelatine in preventing insulin loss from insulin containing solutions. It is probable that this has led to falsely elevated levels of insulin-like activity (ILA) reported with bio-assays. Preparations of crystalline human albumin have been found to be free from ILA and from insulin measured by the radio-immuno-assay. Other human albumin prepared by acid-ethanol extraction (that has been shown previously to contain insulin antagonistic properties on the isolated rat hemidiaphragm) has contained significant ILA on the isolated rat fat pad and also contained insulin demonstrable by radio-immuno-assay.

Resumé. Il a été démontré que l'albumine peut prévenir mieux que la gélatine la perte d'insuline d'une solution contenant de l'insuline. Ceci a probablement conduit à des rapports erronés de taux d'ILA élevés dans les dosages avec des méthodes biologiques. Des préparations d'albumine humaine cristalline ne montraient ni d'ILA, ni d'insuline décelable par la méthode radioimmunologique. L'albumine humaine préparée après extraction par l'alcool-acide (qui dans des expériences antérieures a démontré des propriétés anti-insuliniques avec l'hémidiaphragme isolé du rat) montre une ILA considérable avec le tissu adipeux isolé du rat et aussi de l'insuline qui peut être démontrée par la méthode radioimmunologique.

Zusammenfassung. Es konnte gezeigt werden, daß Albumin stärker als Gelatine den Insulinverlust insulinhaltiger Lösungen verhindern kann. Das hat wahrscheinlich zu falsch erhöhten Spiegeln der insulinähnlichen Aktivität (ILA) geführt, über die bei Bestimmung mit biologischen Methoden berichtet wurde. Präparate kristallinen menschlichen Albumins zeigten keine ILA und auch kein mit der radioimmunologischen Methode bestimmbares Insulin. Menschliches durch Säurealkoholextraktion gewonnenes Albumin (das nach früheren Untersuchungen insulinantagonistische Eigenschaften am isolierten Rattenhemidiaphragma hat) zeigte am isolierten Rattenfettgewebe eine deutliche ILA und auch mit der radioimmunologischen Methode bestimmbares Insulin.
That ${ }^{131}$ I labelled insulin may be non-specifically adsorbed onto glass and other surfaces, has been established for a number of years (FERREBEE et al. $(1951)^{2}$, HILL (1959) $)^{4}$, NEWERLY and Bersor $\left.(1957)^{8}\right)$. This may be competitively inhibited by the addition of an exogenous protein; unlabelled insulin appears to be more effective in this respect than either albumin or gamma globulin. The degree of inhibition of insulin adsorption appears to be partly related to the concentration of protein added.

We have examined the relative abilities of albumin (used in most immuno-assays) and gelatine (used in most bio-assays) in preventing the loss of unlabelled insulin from standard solutions used in bio-assay.

\section{Method}

A stock solution of pure beef insulin was prepared to contain $10 \mathrm{U} / \mathrm{ml}$. This was then frozen in aliquots. On each day an aliquot was thawed and diluted in an identical manner to give a solution calculated to contain $250 \mu \mathrm{U} / \mathrm{ml}$. insulin. Dilution was performed in Krebs'-Ringer bicarbonate buffer either in the absence of any additional protein or after the addition of albumin $2 \mathrm{mg} / \mathrm{ml}$ or gelatine $2 \mathrm{mg} / \mathrm{ml}$. An aliquot of each solution $(250 \mu \mathrm{U} / \mathrm{ml}$.) was frozen immediately, the remainder was then transferred through 12 ordinary glass test tubes with gentle mixing in each and a further aliquot taken and frozen.

The insulin contents of these solutions were measured by immuno-assay using the double antibody precipitation technique of HALES and RANDLE (1963) ${ }^{3}$.

We have examined the validity of measuring insulin by immuno-assay when it is in solution with gelatine. It appears that the addition of gelatine to the unknown solution under investigation does not affect the precipitation of the insulin-anti-insulin complex by the anti-gamma globulin serum.

Additional experiments were performed using the isolated rat epididymal fat pad bio-assay, measuring the conversion of glucose-1. ${ }^{14} \mathrm{C}$ to ${ }^{14} \mathrm{CO}_{2}$ (SöNKSEN et al. $\left.(1965)^{10}\right)$.

The albumin preparations used in these experiments had previously been examined at various concentrations for insulin-like activity (ILA) with the fat pad bio-assay and for insulin by immuno-assay.

\section{Results}

The mean insulin content of the three solutions before and after transfer through the test tubes is shown in Fig. 1.

These values were obtained by radio-immuno-assay utilizing a guinea-pig antiserum to pork insulin and 
are quoted in terms of human insulin. This probably accounts for the discrepancy between the calculated concentration of $250 \mu \mathrm{U} / \mathrm{ml}$ for the beef insulin solutions and the mean value of $298 \mu \mathrm{U} / \mathrm{ml}$ obtained by assay of the albumin containing solutions. The discrepancy cannot be explained by insulin contamination of the albumin preparation since it had previously been tested at concentrations up to $40 \mathrm{mg} / \mathrm{ml}$ and had been found to contain no insulin.

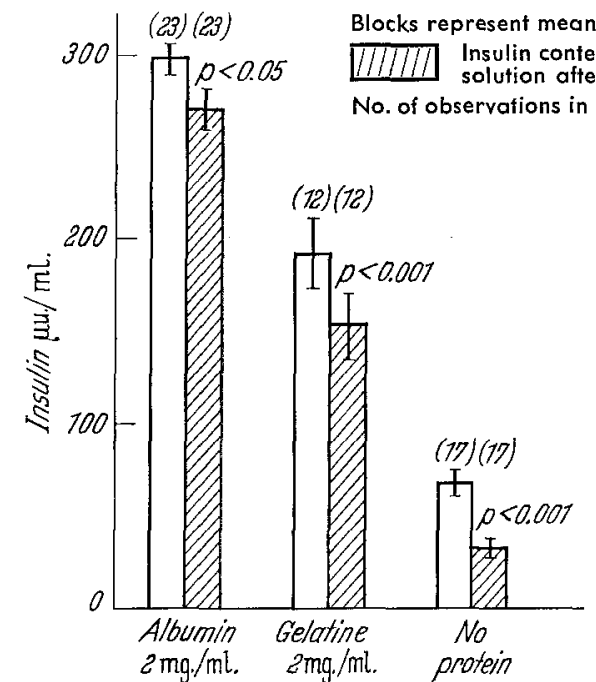

Fig. 1. Insulin solutions prepared by dilution of a stock solution containing $10 \mathrm{U} / \mathrm{ml}$, in Krebs' bicarbonate buffer solution containing gelatine $2 \mathrm{mg} / \mathrm{ml}$ or no added protein, were found to have a lower insulin concentration by radio-immuno-assay than a solution prepared in an identical manner, but containing albumin $2 \mathrm{mg} / \mathrm{mI}$

There is further insulin Ioss from all solutions during transfer through 12 glass test tubes. The overall loss of insulin is least in the albumin containing solution

The mean insulin content of the solution prepared in the absence of added protein is very low and indicates the magnitude of the losses that will occur under these circumstances. The mean of the gelatine containing solutions falls midway between the solution prepared in the absence of added protein and the solution prepared with added albumin.

There is further significant insulin loss from all the solutions during transfer through the test tubes; this loss is least in the albumin-containing solutions, being significant only at the $5 \%$ level. With the other two solutions the additional fall after transfer is highly significant at the $0.1 \%$ level.

When an unknown serum was tested in bio-assay against standards prepared in albumin and in gelatine, the ILA of the serum was always less when calculated in terms of the albumin containing standards. This is illustrated in Fig. 2 where the same serum has been measured on two occasions against two sets of standards. The ILA in terms of "albumin" standards remains approximately constant on the two occasions, whereas the ILA in terms of the "gelatine" standards is more variable and, on both occasions, much higher.
The albumin used in these experiments was fraction $\mathrm{AP}_{3}$ prepared from pooled human plasma by the method of Kenwick and McKay (1954) ${ }^{6}$. None of the three batches so far tested has contained significant ILA when measured at concentrations of up to $40 \mathrm{mg} / \mathrm{ml}$; nor has any contained insulin detectable by immuno-assay. On polyacrylamide electrophoresis they were found to contain significant amounts of $\alpha_{1}$ and $\alpha_{2}$ globulins as well as albumin.

We have found that some of the albumin preparations obtained by Lowr, Blanshard and Phear in $1961^{7}$, by trichloracetic acid (TCA) precipitation from the plasma of diabetic patients and normal subjects, and shown by them to inhibit the action of insulin in the isolated rat hemidiaphragm bio-assay, have contained high levels of ILA on the fat pad and as much as $25 \mathrm{mU}$ of insulin per gram of albumin by immunoassay. This is in agreement with the results of KEEN $(1963)^{5}$, and Alp and RECANT (1964)1. Not all of this ILA was neutralised or "suppressed" by guinea pig anti-insulin serum. The antibody "suppressible" fraction appeared to correlate well with insulin content determined by the radio-immuno-assay.

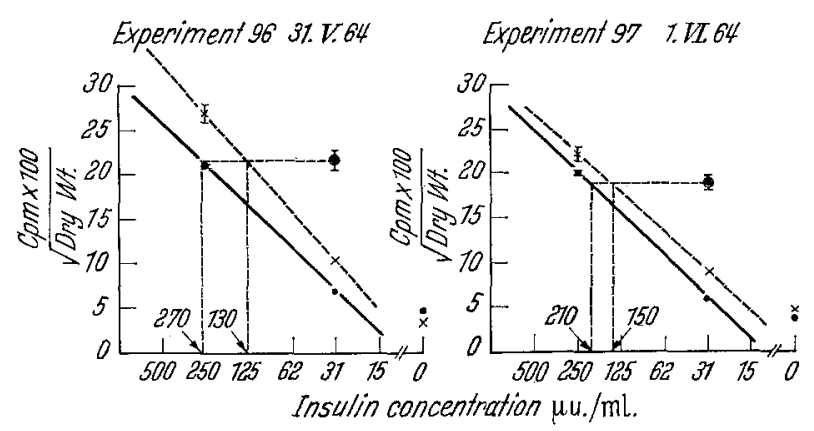

Fig. 2. In the two experiments shown here, the same serum $(\odot)$ has been measured on two occasions against standard insulin solutions prepared with added gelatine $(-\cdot-)$ and with albumin $(---x---)$. The apparent ILA of the serum is shown on the abscissa in terms of the two sets of standards. The 'albumin' ILA is lower on both occasions. Each point represents the mean \pm one standard deviation

\section{Discussion}

The observed loss of insulin from standard insulin solutions containing gelatine is of particular interest since most of the published data for ILA in plasma has been obtained by reference to standards prepared with gelatine. These results suggest that the plasma ILA reported in terms of standards prepared with gelatine will be falsely high. It is probable that this phenomenon is in part responsible for the higher plasma insulin values found when bio-assay is compared with immuno-assay. The data also show that albumin, at a concentration of $2 \mathrm{mg} / \mathrm{ml}$, is not totally effective in preventing insulin adsorption to glass.

There has been controversy concerning the insulin content of albumin preparations (RENoLD, 1964). ${ }^{9}$ None of the three batches of human albumin 
that we have obtained from the Lister Institute exhibited any significant contamination with insulin at a concentration of $40 \mathrm{mg} / \mathrm{ml}$. It appears therefore, to be quite safe to use these preparations in bio-assay at a concentration of $2 \mathrm{mg} / \mathrm{ml}$. The albumin preparations obtained by TCA precipitation have on several occasions contained relatively large amounts of insulin. On polyacrylamide electrophoresis these preparations appear to be as pure as the Lister albumin. That these preparations will inhibit insulin in one bio-assay while producing a marked insulin-like effect in another is a fact that awaits explanation.

This work was carried out while one of us (P.H.S.) was working as a Leverhulme Research Fellow and (A.R.) was supported by a grant from the British Diabetic Association.

We are grateful to Dr. W. MAxcook of the Lister Institute for a supply of highly purified Human Albumin.

\section{References}

1 Arp, H., and L. RECANT : Effect of the insulin-inhibitory albumin fraction from normal and diabetic subjects on adipose tissue. Metabolism 13, 609-619 (1964).

2 Frrreaber, J.W., B.B. Johnson, J.C. MTthoefer and J.W. GaRDELTA: Insulin and adrenocorticotropin labelled with radio-iodine. Endocrinology 48, 277283 (1951).

${ }^{3}$ HaLES, C.N., and P.J. RandeE: Immunoassay of insulin with insulin-antibody precipitate. Biochem. J. 88, 137-146 (1963).

${ }^{4}$ HruL, J.B.: The adsorption of $\mathrm{I}^{131}$-insulin to glass. Endocrinology 65, 515-517 (1959).

$5 \mathrm{KEEN}, H$. . Properties of human "albumin". A metabolic study of albumin extracts from normal and diabetic plasma. Diabetes 12, 406-413 (1963).

${ }^{6}$ KEKWICK, R.A., and M.E. McKAY: The separation of protein fractions from human plasma with ether. Spec. Rep. Ser.med. Res. Coun. (Lond.) (1954) No. 286

${ }^{7}$ Lowy, C., G. Blanshard and D. Phear: Antagonism of insulin by albumin. Lancet 1961 I, 802-804.

${ }^{8}$ NEWERLY, K., and S.A. BERSON : Lack of specificity of insulin- $\mathrm{I}^{131}$-binding by isolated rat diaphragm. Proc. Soc. Exper. Biol. and Med. 94, 751-755 (1957).

${ }^{9}$ Renold, A.E., Discussion of the paper by KIPNIS, D., and M.F. SrEIN : Insulin Antagonism : fundamental considerations. CIBA Foundation Colloquia on Endocrinology 15, 185-186 (1964).

10 Sönksen, P.H., J.P. Ellis, C. Lowy, A. RuTHERford and J.D.N. NABARRo: Plasma insulin: a correlation between bioassay and immunoassay. Brit. Med. J. 1965 II, $209-210$.

Dr. P.H. SÖNKSEN

Institute of Clinical Research

Middlesex Hospital Medical School

40 Hanson Street

London W. 1 / England 